\title{
PEMBERDAYAAN KOMITE SEKOLAH DALAM MENINGKATKAN EFISIENSI PENGELOLAAN SEKOLAH DI KOTA DEPOK (Studi Kasus pada Komite SMAIT Al-Qudwah Kota Depok)
}

\author{
Marsofiyati \\ Fakultas Ekonomi, Universitas Negeri Jakarta \\ Susan Febriantina \\ Fakultas Ekonomi, Universitas Negeri Jakarta
}

\begin{abstract}
This study aims to determine the school committee in an effort to empower SMAIT Al Qudwah Depok City in order to improve the efficiency of school management. This research was qualitative research site in SMAIT Al Qudwak Depok. The data source research is the principal, vice principal, school board committees as well as some students. Collecting data using the method of observation, interviews, documentation and archive footage, while the analysis of data using qualitative data analysis interactive model. The results showed that: (1) The Board committee at Al-Qudwah SMAIT Depok City consists of various professions and have a minimum education level Bachelor (S1); (2) Implementation of the program of work of the school committee in SMAIT Al Qudwah Kota Depok yet fully effective. It is characterized by not fahamnya school board committee will function and role of the school committee in improving the efficiency of school management in schools; (3) Empowerment committee at Al-Qudwah SMAIT Depok City has not fully maximized. It is characterized by the limited space of empowerment for the management committee of the school as a partner school. Besides, the school has not fully facilitate the school committee to explore the potential of its staff so that its existence can be empowered.
\end{abstract}

Keywords: characteristics, role and functions, empowerment, school committees 


\section{PENDAHULUAN}

Pendidikan merupakan kunci kemajuan suatu bangsa. Hal ini dikarenakan pendidikan berkontribusi langsung dalam mengembangkan sumber daya manusia (SDM) yang berkualitas sehingga dapat mendukung perkembangan ekonomi, ilmu pengetahuan dan teknologi serta budaya di negara tersebut. Karena itu, semakin berefisiensi pengelolaan sekolah suatu bangsa, semakin berkualitaslah bangsa dan negara tersebut.

Pendidikan Nasional sebagaimana dinyatakan dalam Undang-Undang Indonesia Nomor 20 Tahun 2003 bertujuan untuk meningkatkan kualitas sumber daya manusia Indonesia yang beriman dan bertaqwa kepada Tuhan Yang Maha Esa, berbudi pekerti luhur, berkepribadian, bekerja keras, tangguh, bertanggung jawab, mandiri, cerdas dan terampil serta sehat jasmani dan rohani. Melalui pendidikan nasional inilah diharapkan bangsa Indonesia akan segera menjadi bangsa dan negara yang maju.

Sayangnya pendidikan di Indonesia yang merupakan salah satu aspek penentu Indeks Pembangunan Manusia (IPM) belum mampu mengangkat peringkat IPM Indonesia. Hal itu terlihat dalam laporan United Nation Development Program (UNDP) tentang Indeks Pembangunan Manusia (IPM) tahun 2011. Indeks itu menyatakan bahwa IPM Indonesia pada 2011 ini adalah 0,617. Ini berarti dari segi peringkat, kualitas hidup manusia Indonesia kini berada di posisi ke-124 dari 187 negara. IPM Indonesia itu masih di bawah IPM negara-negara Asia Timur dan Pasifik yang berada di angka 0,671 . Dengan demikian kualitas manusia Indonesia masih belum cukup membanggakan, bahkan di tingkat Asia Pasifik sekalipun. ${ }^{1}$ Menyadari pentingnya proses peningkatan kualitas sumber daya manusia, maka pemerintah telah berupaya mewujudkan amanat tersebut melalui berbagai usaha pembangunan pendidikan yang lebih berkualitas melalui pengembangan dan perbaikan kurikulum dam sistem evaluasi, perbaikan sarana pendidikan, pengembangan dan pengadaan materi ajar, serta pelatihan bagi guru dan tenaga kependidikan lainnya. Tetapi kenyataan belum cukup dalam meningkatkan efisiensi pengelolaan sekolah .

Dalam paradigma baru, proses penyelenggaraan pendidikan menggunakan pola manajemen berbasis sekolah (MBS) yang salah satu hal pokok penerapannya adalah otonomi pemberdayaan sekolah dan pemberdayaan seluruh sumber daya sekolah. Salah satu sumber daya sekolah yang berpotensi adalah keterlibatan dan partisipasi masyarakat sekitar sekolah dan orang tua peserta didik. 
Di bentuknya suatu badan yang mengganti keberadaan Badan Pembantu Penyelenggara Pendidikan (BP3) yakni komite sekolah melalui keputusan Menteri Pendidikan Nasional nomor: 004/U/2002 tanggal 2 april 2002 tentang dewan pendidikan dan komite sekolah membuka jalur lebih besar dalam meningkatkan keterlibatan dan partisipasi masyarakat sekitar terhadap proses penyelenggaraan pendidikan di sebuah sekolah. Penggantian nama BP3 menjadi Komite Sekolah didasarkan atas perlunya keterlibatan masyarakat secara penuh dalam meningkatkan efisiensi pengelolaan sekolah.

Salah satu tujuan pembentukan Komite Sekolah adalah meningkatkan tanggung jawab dan peran serta masyarakat dalam penyelenggaraan pendidikan di satuan pendidikan. Hal ini berarti peran serta masyarakat sangat dibutuhkan dalam meningkatan mutu pendidikan, bukan hanya sekedar memberikan bantuan berwujud material saja, namun juga diperlukan bantuan berupa pemikiran, ide, dan gagasangagasan inovatif demi kemajuan suatu sekolah.

Seiring dengan kemajuan zaman, di mana era keterbukaan menjadi salah satu landasannya, keterlibatan masyarakat sekitar dan orang tua peserta didik yang diwadahi melalui komite sekolah, tidak berarti juga proses penyelenggaraan pendidikan di sekolah lepas dari permasalahan. Beberapa permasalahan yang terkait dengan komite sekolah bermunculan diantaranya; munculnya pungutan liar dalam pelaksanaan dan penerimaan peserta didik baru (PPDB) oleh komite sekolah, ${ }^{2} \quad$ kurang kuatnya peranan komite sekolah dalam perencaanaan, penganggaran, penggunaan dan pertanggung jawaban dana BOS, ${ }^{3}$ kisruh antara komite sekolah dengan pihak manajemen sekolah, ${ }^{4}$ hingga kinerja komite sekolah yang perlu dievaluasi ${ }^{5}$ dan permasalahan lainnya.

Berdasarkan

permasalahan-permasalahan di atas dan studi pendahuluan, terdapat beberapa hal yang perlu perbaikan dan penyempurnaan organisasi komite sekolah yaitu: (1) penguatan organisasi komite sekolah; (2) penguatan peran dan fungsi komite sekolah dalam manajemen sekolah; peningkatan kapasitas pengurus komite sekolah berkaitan denagan manajemen sekolah; dan (4) dukungan yang kuat dari komite sekolah terhadap program sekolah. Kemudian secara umum ditemukan bahwa keterwakilan lapisan masyarakat dalam kepengurusan komite sekolah 
belum sepenuhnya memenuhi aspirasi masyarakat, karena ada diantaranya hanya merubah nama BP3 menjadi komite sekolah, sedangkan pengurusnya tetap. Selain itu "ketegangan" yang sering terjadi antara komite sekolah dengan pihak sekolah (terutama Kepala Sekolah) memperlihatkan belum terjalinnya prinsip kemitraan yang baik.

Secara umum kemampuan pengurus komite sekolah menggerakkan organisasinya dan membantu meningkatkan kualitas manajemen sekolah masih perlu dikembangkan karena berbagai keterbatasan. Oleh sebab itu cukup mendesak dilakukan upaya meningkatkan pemberdayaan komite sekolah untuk peningkatan kemampuan mengelola organisasi sekaligus meningkatkan efisiensi pengelolaan sekolah.

Meski demikian peneliti juga mengamati di lapangan, bahwa di beberapa sekolah Islam khususnya di kota Depok, komite sekolah dapat menjadi partner yang baik bagi sekolah tersebut. Mulai dari pengambilan keputusan semua proses pendidikan, keterlibatan dalam kegiatan kurikulum dan kesiswaan, hingga evaluasi penyelenggaraan pendidikan di sekolah. Komite sekolah di beberapa sekolah Islam terpadu di kota Depok bahkan telah difasilitasi dengan fasilitas yang memadai seperti; ruangan khusus komite, struktur organisasi yang kuat, AD/ART yang lengkap, dan kepengurusan yang kompak.

Berdasarkan latar belakang tersebut maka peneliti tertarik mengadakan penelitian yang berjudul: "Pemberdayaan Komite Sekolah dalam Meningkatkan Efisiensi pengelolaan sekolah di Kota Depok. (Studi Kasus pada Komite SMAIT Al-Qudwah Kota Depok)"

\subsection{Identifikasi Masalah}

Identifikasikan permasalahan sebagai berikut:

1. Penguatan organisasi komite sekolah belum maksimal.

2. Peningkatan kapasitas pengurus komite sekolah belum maksimal.

3. SDM Komite sekolah belum tepat guna secara maksimal.

4. Karakteristik komite sekolah yang homogen.

5. Kurangnya sosialisasi tugas dan peran komite sekolah.

6. Kurangnya peran dan fungsi komite sekolah terhadap pengembangan mutu pendidikan.

7. Pemberdayaan komite sekolah belum maksimal

\subsection{Perumusan Masalah}

Perumusan permasalahan sebagai berikut:

1. Bagaimana karakteristik komite sekolah di SMAIT Al-Qudwah Kota Depok?

2. Bagaimana peran dan fungsi komite sekolah di SMAIT AlQudwah Kota Depok? 
3. Bagaimana pemberdayaan komite sekolah di SMAIT AlQudwah Kota Depok?

\subsection{Tujuan Penelitian}

Tujuan penelitian ini

adalah sebagai berikut:

1. Untuk mengetahui karakteristik komite sekolah SMAIT AlQudwah Depok.

2. Untuk mengetahui peran dan fungsi komite sekolah SMAIT Al-Qudwah Depok.

3. Untuk mengetahui pemberdayaan komite sekolah SMAIT Al-Qudwah Depok.

\subsection{Kontribusi Penelitian}

Hasil

Kontribusi hasil penelitian ini adalah sebagai berikut:

1. Bahan masukan dalam pemberdayaan komite sekolah khususnya di SMAIT AlQudwah di Kota Depok.

2. Menambah khazanah pustaka tentang pemberdayaan komite sekolah dalam rangka meningkatkan mutu pendidikan.

\section{TINJAUAN PUSTAKA}

\subsection{Komite Sekolah}

\subsubsection{Pengertian Komite}

\section{Sekolah}

Dasar hukum

pembentukan komite sekolah adalah Kepmendiknas No.044/U/ 2002 dan UUSPN No. 20/2003. Berdasarkan pasal 1 poin 25 UUSPN No.20/2003 dinyatakan bahwa komite sekolah/madrasah adalah lembaga mandiri yang beranggotakan orang tua/wali peserta didik, komunitas sekolah, serta tokoh masyarakat yang peduli pendidikan 6 . Selanjutnya pasal 56 ayat (1) menegaskan bahwa masyarakat berperan dalam peningkatan mutu pelayanan pendidikan yang meliputi perencanaan, pengawasan, dan evaluasi program pendidikan melalui dewan pendidikan dan komite sekolah/madrasah. Berkaitan dengan komite sekolah UUSPN No. 20/2003 pasal 56 ayat (3) menyatakan bahwa komite sekolah/madrasah, sebagai lembaga mandiri, dibentuk dan berperan dalam peningkatan mutu pelayanan dengan memberikan pertimbangan, arahan dan dukungan tenaga, sarana dan prasarana, serta pengawasan pendidikan pada tingkat satuan pendidikan.

Adapun tujuan pembentukan Komite Sekolah menurut Kepmendiknas nomor 044/U/2002 adalah:

1. Mewadahi dan menyalurkan aspirasi serta prakarsa masyarakat dalam melahirkan kebijakan operasional dan program pendidikan di satuan pendidikan.

2. Meningkatkan tanggung jawab dan peran serta masyarakat dalam penyelenggaraan pendidikan di satuan pendidikan.

3. Menciptakan suasana dan kondisi transparan, akuntabel, dan demokratis dalam 
penyelenggaraan dan pelayanan pendidikan yang bermutu di satuan pendidikan.

Dalam SK Mendiknas RI No. 044/U/2002 tentang Dewan Pendidikan dan Komite Sekolah disebutkan Komite Sekolah berfungsi:

$\begin{array}{lr}\text { a. Mendorong } & \text { tumbuhnya } \\ \text { perhatian dan } & \text { komitmen } \\ \text { masyarakat } & \text { terhadap } \\ \text { penyelenggaraan } & \text { pendidikan } \\ \text { yang bermutu; } & \end{array}$

b. Melakukan kerjasama dengan masyarakat (perorangan/ organisasi/ dunia usaha/dunia industri) dan pemerintah berkenaan dengan penyelenggaraan pendidikan yang bermutu;

c. Menampung dan menganalisis aspirasi, ide, tuntutan, dan berbagai kebutuhan pendidikan yang diajukan oleh masyarakat;

d. Memberikan masukan, pertimbangan, dan rekomendasi kepada satuan pendidikan mengenai: 1) kebijakan dan program pendidikan; 2) Rencana Anggaran Pendidikan dan Belanja Sekolah (RAPBS); 3) kriteria kinerja satuan pendidikan; 4) kriteria tenaga kependidikan; 5) kriteria fasilitas pendidikan; dan 6) hal-hal lain yang terkait dengan pendidikan;

e. Mendorong orangtua dan masyarakat berpartisipasi dalam pendidikan guna mendukung peningkatan mutu dan pemerataan pendidikan;

f. Menggalang dana masyarakat dalam rangka pembiayaan penyelenggaraan pendidikan disatuan pendidikan;

g. Melakukan evaluasi dan pengawasan terhadap kebijakan, program, penyelenggaraan, dan keluaran pendidikan di satuan pendidikan.

Komite sekolah merupakan sebuah organisasi formal yang ada di sekolah, yang dalam hal ini kedudukannya sejajar dengan kepala sekolah. Hal ini dikarenakan komite sekolah merupakan partner dari sekolah yang akan turut berpartisipasi dalam meningkatkan efisiensi pengelolaan sekolah di sekolah. Organisasi komite sekolah terdiri atas keanggotaan dan kepengurusan komite sekolah.

1. Keanggotaan Komite Sekolah

- Keanggotaan Komite Sekolah terdiri atas unsur masyarakat dapat berasal dari (1) orang tua/wali peserta didik; (2) tokoh masyarakat; (3) tokoh pendidikan; (4) dunia usaha/industri; (5) organisasi profesi tenaga pendidikan; (6) wakil alumni; (7) wakil peserta didik dan unsur dewan guru, yayasan/lembaga penyelenggara pendidikan.

- Anggota Komite Sekolah sekurang-kurangnya berjumlah 9 (sembilan) orang dan jumlahnya gasal.

2. Kepengurusan Komite Sekolah

- Pengurus komite sekolah sekurang-kurangnya terdiri atas ketua, sekretaris dan bendahara. 
- Pengurus dipilih dari dan oleh anggota.

- Ketua bukan berasal dari kepala satuan pendidikan.

3. Anggaran Dasar (AD) dan Anggaran Rumah Tangga (ART).

- Komite Sekolah wajib memiliki AD dan ART.

- Anggaran Dasar sebagaimana dimaksud sekurangkurangnya memuat: a) Nama dan tempat kedudukan; b) Dasar, tujuan dan kegiatan; c) Keanggotaan dan kepengurusan; d) Hak dan kewajiban anggota dan pengurus; e) Keuangan; f) Mekanisme kerja dan rapatrapat; dan g) Perubahan AD dan ART serta pembubaran organisasi.

\subsubsection{Pembentukan Komite Sekolah}

a. Prinsip Pembentukan

Pembentukan Komite Sekolah menganut prinsip-prinsip 1) transparan, akuntabel, dan demokratis; dan 2) merupakan mitra satuan pendidikan.

b. Mekanisme Pembentukan

1. Pembentukan Panitia
Persiapan
$\begin{aligned} & \text { i). Masyarakat dan/atau kepala } \\ & \text { satuan pendidikan } \\ & \text { membentuk }\end{aligned}$ panitia
persiapan. Panitia persiapan
berjumlah
kurangnya 5 (lima) orang
yang terdiri atas kalangan
praktisi pendidikan (seperti
guru, kepalar satuan
pendidikan, penyelenggara
pendidikan), pemerhati
pendidikan (LSM peduli
pendidikan,

masyarakat, tokoh agama, dunia usaha dan industri), dan orangtua peserta didik.

ii). Panitia persiapan bertugas mempersiapkan

pembentukan Komite Sekolah dengan langkahlangkah sebagai berikut:

- Mengadakan forum sosialisasi kepada masyarakat (termasuk pengurus/ anggota BP3, Majelis Sekolah, dan Komite Sekolah yang sudah ada) tentang Komite Sekolah menurut Keputusan ini;

- Menyusun kriteria dan mengindentifikasi calon anggota berdasarkan usulan dari masyarakat;

- Menyeleksi calon anggota berdasarkan usulan dari masyarakat;

- Mengumumkan namanama calon anggota kepada masyarakat Menyusun nama-nama anggota terpilih;

- Memfasilitasi pemilihan pengurus dan anggota Komite Sekolah;

- Menyampaikan nama pengurus dan anggota kepada kepala satuan pendidikan:

iii). Panitia Persiapan dinyatakan bubar setelah Komite Sekolah terbentuk.

2.Penetapan pembentukan Komite Sekolah.

3. Komite Sekolah ditetapkan untuk pertama kali dengan Surat Keputusan kepala satuan pendidikan, dan 
selanjutnya diatur dalam AD dan ART.

\subsubsection{Tata Hubungan Antar Organisasi Komite Sekolah}

Tata hubungan antara Komite Sekolah dengan satuan pendidikan, Dewan Pendidikan, dan institusi lain yang bertanggungjawab dalam pengelolaan pendidikan dengan Komite Sekolah pada satuan pendidikan lain bersifat koordinatif (SK Mendiknas RI No. 044/U/2002 tentang Dewan Pendidikan dan Komite Sekolah).

\subsection{Peran dan Fungsi Komite Sekolah}

Pendidikan adalah

tanggung jawab bersama antara orang tua siswa, masyarakat dan pemerintah. Namun sayangnya tanggung jawab tersebut belum optimal, terutama peran serta masyarakat sampai saat ini belum banyak diberdayakan. Dalam UU No. 20/ 2003 tentang Sisdiknas, pasal Pasal 56 disebutkan bahwa Dewan Pendidikan dan Komite Sekolah atau Komite Madrasah memiliki peran sebagai berikut: 1) Masyarakat berperan dalam peningkatan mutu pelayanan pendidikan yang meliputi perencanaan, pengawasan, dan evaluasi program pendidikan melalui dewan pendidikan dan komite sekolah/madrasah. 2) Dewan pendidikan sebagai lembaga mandiri dibentuk dan berperan dalam peningkatan mutu pelayanan pendidikan dengan memberikan pertimbangan, arahan dan dukungan tenaga, sarana dan prasarana serta pengawasan pendidikan pada tingkat nasional, provinsi, dan kabapaten/kota yang tidak mempunyai hubungan hierarkis.

sekolah/madrasah

3) Komite sebagai lembaga mandiri dibentuk dan berperan dalam peningkatan mutu pelayanan dan memberikan pertimbangan, arahan dan dukungan tenaga, sarana dan prasarana serta pengawasan pendidikan pada tingkat satuan pendidikan.

Atas dasar pemberdayaan masyarakat dalam pendidikan, maka dibentuk komite sekolah yang didasarkan atas Kepmendiknas No. 044/U/2002, yang keberadaannya berperan sebagai berikut: 1) Pemberi pertimbangan (advisory agency) dalam penentuan dan pelaksanaan kebijakan pendidikan di satuan pendidikan; 2) Pendukung (supporting agency) baik yang berwujud finansial, pemikiran, maupun tenaga dalam penyelenggaraan pendidikan di satuan pendidikan; 3) Pengontrol (controlling agency) dalam rangka transparansi dan akuntabilitas penyelenggaraan dan keluaran pendidikan di satuan pendidikan; dan 4) Mediator antara pemerintah (eksekutif) dan dengan masyarakat di satuan pendidikan.

$$
\text { Untuk }
$$

memberdayakan

dapat dan 208 
meningkatkan peran masyarakat, sekolah harus dapat membina kerjasama dengan orang tua dan masyarakat, menciptakan suasana kondusif dan menyenangkan bagi peserta didik dan warga sekolah. Dengan demikian, penyelenggaraan Manajemen Berbasis Sekolah yang mengandung makna sebagai manajemen partisipatif yang melibatkan peran serta masyarakat dapat terlaksana dengan baik.

\subsection{Pemberdayaan Komite Sekolah}

Salah satu ciri dari penerapan model manajemen berbasis sekolah (MBS) adalah penyusunan rencana, program, dan kegiatan sekolah disusun secara partisipatif, transparan dan akuntabel. Dalam MBS, sekolah diharapkan mengenal kekuatan dan kelemahan, potensi, peluang dan ancaman yang dihadapi. Pengenalan diri sekolah tersebut, sebagai dasar dalam menentukan kebijakan pendidikan yang akan diambil?.

Berdasarkan analisis tersebut, sekolah merumuskan visi, misi, sasaran dan menyusun strategi serta menetapkan program pengembangan untuk jangka waktu tertentu. MBS dikembangkan dengan kesadaran bahwa setiap sekolah memiliki kondisi dan situasi serta kebutuhan yang berbeda-beda.
Penyelenggaran

pendidikan model MBS, mengharuskan setiap sekolah harus melibatkan masyarakat setempat (berupa komite sekolah) dalam pengembangan pendidikan. Sumber-sumber yang ada dalam masyarakat diberdayakan seoptimal mungkin, baik sumber daya manusia maupun sumber dana untuk pendidikan.

Sekolah menjadi tanggung jawab masyarakat (komite sekolah), dan sekolah tidak bekerja sendirian untuk memajukan pendidikan. Keberadaan Komite Sekolah bersama Dewan Pendidikan secara legal formal telah dituangkan dalam Kepmendiknas No. 044/U/2002. Berdasarkan Kepmen tersebut, komite sekolah merupakan sebuah badan mandiri yang mewadahi peran serta masyarakat dalam rangka meningkatkan mutu, pemerataan, dan efisiensi pengelolaan pendidikan di satuan pendidikan. Untuk penamaan badan tersebut disesuaikan dengan kondisi dan kebutuhan daerah masing-masing satuan pendidikan, seperti Komite Sekolah, Majelis Madrasah, Majelis Sekolah, atau nama lainnya. Komite sekolah yang berkedudukan di setiap satuan pendidikan, merupakan badan mandiri yang tidak memiliki hubungan hierarkis dengan lembaga pemerintahan. Adapun tujuan komite sekolah menurut Tilaar (2004) yaitu: 1) mewadahi dan menyalurkan aspirasi dan 
prakarsa masyarakat dalam melahirkan kebijakan operasional dan program pendidikan di satuan pendidikan, 2) meningkatkan tanggungjawab dan peran masyarakat dalam penyelenggaraan pendidikan, dan 3) menciptaan suasana dan kondisi transparansi, akuntabel, dan demokratis dalam penyelenggaraan dan pelayanan pendidikan yang bermutu di satuan pendidikan.

\section{METODOLOGI PENELITIAN \\ 3.1. Tempat dan Waktu Penelitian}

Penelitian ini bertempat di SMA Islam Terpadu Depok, yakni SMAIT Al-Qudwah. Penelitian ini dilakukan selama tujuh bulan (April-November 2015).

\subsection{Subyek Penelitian dan} Sumber Data

Subyek penelitian ini adalah pengurus komite sekolah di SMAIT Al-Qudwah Kota Depok yang berjumlah tiga orang, kepala SMAIT Al-Qudwah Kota Depok beserta jajarannya yang terdiri atas wakil kepala sekolah bidang kurikulum dan wakil kepala sekolah bidang kesiswaan serta beberapa peserta didik di lingkungan SMAIT Al-Qudwah Kota Depok yang berjumlah lima orang. Sedangkan Kepala Sekolah dan Ketua Komite SMAIT AlQudwah Depok merupakan key informan dalam penelitian ini.

$$
\text { Adapun sumber data }
$$

penelitian ini menggunakan multisumber bukti (data), sebagaimana disampaikan Yin bahwa data untuk keperluan studi kasus bisa berasal dari enam sumber, yakni dokumen, rekaman arsip, wawancara, pengamatan langsung, observasi partisipan, dan perangkat-perangkat fisik ${ }^{8}$.

Data yang dikumpulkan dalam penelitian ini berbentuk dokumen berupa bahan-bahan tertulis terkait komite sekolah. Data juga meliputi tempat dan peristiwa sebagai sumber data tambahan yang dilakukan melalui observasi langsung terhadap tempat dan peristiwa yang berkaitan dengan komite sekolah.

\subsection{Obyek Penelitian}

Menurut Suharsimi obyek penelitian adalah "fenomena atau masalah penelitian yang telah diabstraksi menjadi suatu konsep atau variabel. Obyek penelitian ditemukan melekat pada subyek penelitian" 9 . Adapun yang menjadi objek penelitian adalah upaya pemberdayaan komite SMAIT Al-Qudwah Kota Depok.

\subsection{Pendekatan Penelitian Pendekatan penelitian ini termasuk dalam jenis studi deskriptif kualitatif. Studi deskriptif merupakan penelitian yang dilakukan dengan tujuan}


mendeskripsikan

(menggambarkan) tentang sesuatu (obyek penelitian) apa adanya.

Sementara pendekatan kualitatif sering disebut penelitian naturalistik karena, sebagaimana disampaikan Bogdan and Biklen (2007:3) "the reseacher frequents places where the events he or she is interested in naturally occur."

Terdapat enam asumsi yang perlu diperhatikan dalam pendekatan kualitatif, yakni: (1) peneliti kualitatif lebih menekankan perhatian pada proses, bukan pada hasil atau produk; (2) peneliti kualitatif tertarik pada makna-bagaimana orang membuat hidup, pengalaman, dan struktur kehidupannya masuk akal; (3) peneliti kualitatif merupakan instrumen pokok untuk pengumpulan dan analisis data yang didekati melalui instrumen manusia;

(4) peneliti kualitatif melibatkan kerja lapangan; (5) peneliti kualitatif bersifat deskriptif dalam arti tertarik proses, makna, dan pemahaman yang didapat melalui kata atau gambar; dan (6) proses penelitian bersifat induktif, peneliti mengembangkan abstrak, konsep, proposisi, dan teori. ${ }^{10}$

\subsection{Metode Pengumpulan Data}

Teknik pada penelitian kualitatif ini adalah observasi, wawancara, studi dokumentasi dan rekaman arsip. Keempat bentuk teknik pengumpulan data tersebut dalam penggunaannya dapat saling melengkapi dan menunjang sehingga dapat diperoleh informasi yang diperlukan.

1. Observasi

2. Wawancara

3. Studi Dokumentasi

4. Rekaman Arsip

\subsection{Teknik Pengumpulan} Data

Analisis data yang digunakan dalam penelitian kualitatif ini, yakni dengan analisis "interactive model" yang dikembangkan oleh Miles dan Huberman (1984:21) mulai dari data reduction, data display dan conclusion drawing/verification. Alur tersebut digambarkan sebagai berikut:

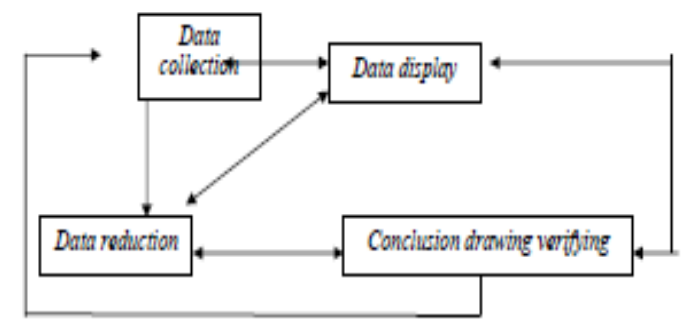

Gambar 1. Model Analisis Interaktif Miles dan Huberman

\subsection{Instrumen Penelitian} Instrumen dalam penelitian ini adalah pedoman wawancara terkait sejarah pembentukan komite sekolah, peran dan fungsi komite sekolah, upaya-upaya pemberdayaan komite sekolah, dan dampak kinerje komite sekolah terhadap 
efisiensi pengelolaan sekolah di SMAIT Al-Qudwah Kota Depok.

\subsection{Kisi-Kisi Instrumen}

Adapun kisi-kisi instrumen dalam penelitian ini adalah sesuai tabel berikut:

Tabel 3.1

Kisi-kisi Instrumen

\begin{tabular}{|c|c|}
\hline VARIABEL & INDIKATOR \\
\hline \multirow[t]{5}{*}{$\begin{array}{l}\text { Pemberdayaa } \\
\text { n Komite } \\
\text { Sekolah }\end{array}$} & $\begin{array}{l}\text { 1. Sejarah } \\
\text { Pembentukan } \\
\text { Komite Sekolah }\end{array}$ \\
\hline & $\begin{array}{l}\text { 2. Peran dan Fungsi } \\
\text { Komite Sekolah }\end{array}$ \\
\hline & $\begin{array}{l}\text { 3. Konsistensi Peran } \\
\text { dan Fungsi } \\
\text { Komite Sekolah }\end{array}$ \\
\hline & 4. Upaya Sekolah \\
\hline & $\begin{array}{l}\text { 5. Dampak Kinerja } \\
\text { Komite Sekolah }\end{array}$ \\
\hline \multirow{2}{*}{$\begin{array}{l}\text { Efisiensi } \\
\text { Pengelolaan } \\
\text { Sekolah }\end{array}$} & $\begin{array}{l}\text { 1. Anggaran dan } \\
\text { Belanja Sekolah }\end{array}$ \\
\hline & $\begin{array}{l}\text { 2. Pengelolaan } \\
\text { Kegiatan dan } \\
\text { Keuangan } \\
\text { Sekolah. }\end{array}$ \\
\hline
\end{tabular}

\section{HASIL PENELITIAN DAN}

\section{PEMBAHASAN}

\subsection{Hasil Penelitian}

\subsubsection{Profil SMAIT Al-} Qudwah Kota Depok

Sebagai bagian dari Yayasan Pendidikan Islam Al-Qudwah Kota Depok, SMAIT Al-Qudwah kota Depok merupakan sekolah Islam terpadu yang memiliki kekhasan tersendiri dibanding sekolah Islam terpadu lainnya di wilayah kota Depok. Dengan visinya "Mencetak generasi berkepribadian Islami, berpengetahuan Qur'ani, dan berwawasan internasional" SMAIT
Al-Qudwah yang didirikan pada tahun 2011 senantiasa mengembangkan dirinya seiring tuntutan masyarakat akan munculnya sekolah menengah atas Islam terpadu yang murah namun berkualitas. Di wilayah kota Depok sendiri, sekolah menengah Islam yang mengusung Islam terpadu (integrasi nilai-nilai Islami dalam semua mata pelajaran dan seluruh aktifitas pembelajaran serta ketercapaian target hafalan Al-Quran sebanyak 30 juz) masih sangat terbatas. Terdapat sekitar tujuh SMAIT yang tersebar di kota Depok, sementara masyarakat di kota Depok sendiri dan sekitarnya sangat antusias untuk memasukkan puteraputerinya ke sekolah menengah atas Islam terpadu yang berkualitas namun terjangkau dari segi biaya sebagai alternatif dari sekolah umum seiring menurunnya kualitas dan moral pendidikan.

Dibandingkan dengan SMAIT lainnya yang ada di wilayah kota Depok, peneliti mengamati bahwa SMAIT AlQudwah masih terbilang baru dan relatif terjangkau oleh masyarakat dari segi biayanya. Hal ini tentu saja tanpa mengurangi efisiensi pengelolaan sekolah di sekolah tersebut yang konsen dan fokus dengan keterpaduan ajaran Islam secara utuh, penguatan nilai-nilai Islami dalam setiap proses pembelajaran serta ketercapaian 
hafalan Al Quran sebanyak 30 Juz.

\subsubsection{Keadaan Komite Sekolah di SMAIT Al- Qudwah Kota Depok}

Komite sekolah di

SMAIT Al-Qudwah Kota Depok terbilang masih baru, hal ini tentu saja dikarenakan sekolahnya juga baru berdiri pada tahun 2011. Seiring berkembangnya system pendidikan di SMAIT Al-Qudwah Kota Depok, maka pada tahun 2012 komite sekolah dibentuk pertama kalinya. Hal ini didasari atas pentingnya komunikasi orang tua siswa, baik komunikasi antara orang tua siswa, maupun komunikasi antara orang tua siswa dengan sekolah. Atas dasar kepentingan komunikasi antara orang tua dengan sekolah dan orang tua dengan orang tua dalam seluruh kegiatan sekolah mulai dari kegiatan utama sekolah yaitu kegiatan belajar mengajar, sampai dengan kegiatan ekstra kurikuler sekolah, maka dibentuklah komite sekolah di SMAIT Al-Qudwah Kota Depok.

Di awal masa pembentukannya, komite sekolah di SMAIT Al-Qudwah Kota Depok masih belum memiliki system yang ajeg, baik terkait struktur organisasinya, kepengurusannya maupun kegiatannya.

\subsubsection{Karakteristik komite sekolah}

Berdasarkan

hasil

penelitian pengurus/anggota komite sekolah di SMAIT AlQudwah Kota Depok telah berpendidikan Sarjana (S-1). Jumlah anggota komite sekolah paling sedikit sebanyak 5 orang dengan kepengurusan komite sekolah berasal dari berbagai unsur perwakilan seperti: tokoh masyarakat, tokoh pendidikan, dewan guru, pengusaha, perwakilan orang tua siswa, dan tokoh agama. Struktur kepengurusan komite sekolah pada umumnya terdiri atas: ketua, wakil ketua, sekretaris, bendahara dan anggota. Bila ditinjau dari jenis pekerjaan pengurus/anggota komite sekolah meraka berasal dari profesi dokter, guru, PNS (selain guru) dan wiraswasta.

\subsubsection{Peran dan fungsi komite sekolah \\ Sebagai organisasi baru di SMAIT Al-Qudwah Kota} Depok, peran dan fungsi komite sekolah mencakup sebagai pemberi pertimbangan dalam hal penentuan dan pelaksanaan kebijakan pendidikan di SMAIT Al-Qudwah Depok. Berkembang lebih lanjut lagi, komite sekolah di SMAIT Al-Qudwah Kota Depok berperan sebagai pengawas dari semua program sekolah baik yang menyangkut akademik maupun non akademik. Dalam hal kepengurusan, komite sekolah di SMAIT Al- 
Qudwah Kota Depok masih belum ajeg, hal ini ditandai dengan perubahan kepengurusan setiap tahunnya namun tahun berikutnya terkadang tidak terbentuk lagi kepengurusan yang baru atau malah tidak jelas akhir periode kepengurusannya. Terkait pembagian tugas, saat ini belum ada pembagian tugas yang jelas dan bertumpu kepada ketua komite sekolah karena belum terbentuknya pengurus dan AD/ART komite sekolah. Adapun pelaksanaan kegiatan dilaksanakan secara bersamasama dengan kesadaran masingmasing anggota.

\subsubsection{Pemberdayaan komite sekolah}

Untuk mengungkap

masalah perberdayaan komite sekolah didasarkan atas data/informasi yang dijaring melalui wawancara. Adapun beberapa hasil wawancara dapat disajikan sebagai berikut:

1. Proses pembentukan komite sekolah dilakukan dengan mengundang orangtua/wali siswa. Setelah forum memenuhi, dilakukan pemilihan kepengurusan dengan memilih ketua. Pemilihan ketua dilakukan secara formatur dan ketua yang terpilih yang menyusun keanggotaan kepengurusan komite sekolah.

2. Rapat-rapat formal dilakukan setidaknya satu kali dalam sebulan dengan melibatkan pihak sekolah.
3. Masih terdapat beberapa orang tua yang sulit berkoordinasi untuk menghadiri rapat-rapat formal.

4. Materi yang dibahas dalam pertemuan

meliputi:

a) Persiapan pelaksanaan Ujian Nasional (UN), b) Prosentase kelulusan siswa kelas XII, c) Prosedur pendaftaran dan penerimaan calon siswa baru, Penjelasan tentang program kerja sekolah, e) membicarakan masalah kesejahteraan dan kinerja guru, dan hal lain yang berhubungan dengan peningkatan mutu pendidikan.

5. Dari hasil wawancara, hampir semua pengurus/anggota komite sekolah belum memahami peran dan fungsi komite sebagaimana diuraikan dalam Kepmen No. 44/U/2002 dalam meningkatkan mutu pendidikan. Hal ini dapat difahami mengingat sekolah ini baru berjalan selama empat tahun. Namun demikian, kedua belah pihak yakni sekolah dan orang tua dalam hal ini komite sekolah sangat intens dan berkomitmen kuat untuk meningkatkan kualitas sekolah.

6. Pengurus/anggota komite sekolah pada umumnya belum pernah mengikuti penataran/ 
workshop/pelatihan tentang pemberdayaan komite sekolah dalam meningkatkan mutu pendidikan.

7. Pengurus/anggota komite sekolah belum memahami RAPBS yang disusun oleh sekolah. Ketua komite sekolah hanya sebatas mengetahui dan menandatangani RAPBS yang diajukan oleh kepala sekolah karena pada saat merencanakan RAPBS dan program-program sekolah tersebut di awal tahun ajaran, komite sekolah sendiri belum terbentuk. Namun pihak sekolah selalu komunikatif terhadap perkembangan programprogram dan pendanaan program-program tersebut. Sehingga sampai dengan saat ini tidak terjadi kesalahfahaman antara pihak sekolah dengan komite sekolah.

8. Komite sekolah juga belum memiliki AD/ART sebagai dasar penyelenggaraan kegiatan/ program komite sekolah sebagai mitra sekolah untuk meningkatkan mutu pendidikan.

\subsection{Pembahasan}

Berdasarkan temuan yang peneliti lakukan dalam proses pengambilan data, pengurus komite sekolah di SMAIT AlQudwah Kota Depok terdiri atas perwakilan orang tua peserta didik dengan profesi yang bermacam-macam, mulai dari dokter, guru, wiraswasta, tokoh masyarakat dan sebagainya dengan jenjang pendidikan minimal sarjana (S1).

Keberagaman pofesi dan tingkat pendidikan yang berbedabeda ini menjadi keunikan tersendiri sehingga komite sekolah di SMAIT Al-Qudwah Kota Depok dapat menggali potensi masing-masing pengurusnya dari kaca mata dan pengalaman masing-masing, sehingga komite sekolah dapat memaksimalkan dirinya dalam berkontribusi terhadap peningkatan efisiensi pengelolaan sekolah di SMAIT Al-Qudwah Kota Depok. Adapun struktur kepengurusan komite sekolah di SMAIT Al-Qudwah Kota Depok yang terdiri atas ketua, sekretaris dan bendahara cukup menggambarkan sebuah organisasi yang layak dan antar sesame pengurus dapat bekerja sama untuk mencapai efisiensi pengelolaan sekolah yang lebih baik. Sayangnya kepengurusan komite sekolah yang sudah terbentuk belum di syahkan secara formal oleh pihak sekolah, antara lain belum di keluarkannya Surat Keputusan terkait pengurus komite sekolah. Hal ini tentunya menjadi kendala tersendiri bagi pihak sekolah, terutama ketika salah satu pengurus komite sekolah mengundurkan diri dari kepengurusannya disebabkan kesibukan dan aktifitas nya diluar atau alasan lainnya. Disamping 
itu kejelasan wewenang dan pembagian kerja setiap pengurus belum terlihat di dalam kepengurusan komite sekolah di SMAIT Al-Qudwah Kota Depok. Masing-masing pengurus masih belum memahami tugas utama mereka di kepengurusan. Meski demikian, pengurus komite di SMAT Al-Qudwah Kota Depok antusias untuk memahami tugas dan peran mereka sebagai komite sekolah. Hal tersebut tentunya sejalan dengan tuntutan UU Nomor 25 Tahun 2002 tentang Program Pembangunan Nasional (Propenas) 2000-2004. Undangundang tersebut kemudian ditindaklanjuti dengan terbitnya Kepmendiknas Nomor 044/U/2002 tentang Dewan Pendidikan dan Komite Sekolah. Tuntutan tersebut tertuang dalam Butir-butir ketentuan yang penting di dalam Kepmendiknas tersebut akhirnya juga diakomodasi dalam UU Nomor 20 Tahun 2003 tentang Sistem Pendidikan Nasional.

\subsubsection{Fungsi dan Peran Komite Sekolah}

Seiring proses perbaikan dan pengembangan kualitas pengelolaan sekolah oleh pihak sekolah dan yayasan, komite sekolah SMAIT Al-Qudwah Kota Depok juga terus membenahi diri khususnya dalam melaksanakan keempat perannya sebagai komite sekolah dalam hal sebagai berikut:
1. Pemberi
pertimbangan
(advisory agency) dalam penentuan
dan pelaksanaan

kebijakan pendidikan di SMAIT Al-Qudwah Kota Depok.

Dalam melaksanakan perannya sebagai pemberi pertimbangan, komite sekolah setidaknya mengadakan rapat dan pertemuan antara pihak sekolah dan pihak orang tua siswa, di mana orang tua memberikan masukanmasukan atau saran-saran kepada pihak sekolah dalam hal program-program yang akan dilaksanakan oleh pihak sekolah misalnya terkait program akademik, komite sekolah turut memberikan masukan terhadap proses pembelajaran yang diterapkan para guru di sekolah dan ketercapaia target hafalan Quran yang menjadi target SMAIT AL-Qudwah Kota Depok.

2. Pendukung

(supporting agency), baik yang berwujud finansial, pemikiran maupun tenaga dalam penyelenggaraan pendidikan di SMAIT Al-Qudwah Depok.

Peran dan fungsi ini dapat dilihat dari berbagai kegiatan/program sekolah yang didukung dengan baik oleh komite sekolah, orang tua dan masyarakat, seperti kegiatan bakti sosial dan penyembelihan hewan kurban pada perayaan idul Qurban. Selain itu komite sekolah SMAIT Al-Qudwah Depok juga berpartisipasi dalam memberikan dana bantuan pembangunan sekolah yang 
hingga saat ini memang masih dalam tahap pengembangan. Pelaksanaan kegiatan tersebut terselenggara atas bantuan pemikiran, tenaga dan finansial dari pihak sekolah, orang tua maupun masyarakat sekitar.

Saat ini komite SMAIT AlQudwah Kota Depok juga sangat konsen memberikan pengawasan pada perkembangan hafalan putraputrinya sebagai peserta didik di SMAIT Al-Qudwah Kota Depok. Pengawasn dilakukan baik secara individu orang tua maupun secara kepengurusan. Secara individu, komite sekola yang diwakili para orang tua peserta didik sennatiasa turut mengawasi ketercapaian hafalan Al Quran putera putrinya sebagaimana yang ditargetkan pihak sekolah yakni hafalan mencapai 10 juz setiap satu tahun pembelajaran sekolah. Secara kepengurusan, komite skolah yang diwakili pengurus juga memberikan motivasi kepada semua orang tua dan peserta didik akan pentingnya menghafal Al Quran.

3. Pengontrol (controlling agency) dalam rangka transparansi dan akuntabilitas penyelenggaraan dan keluaran pendidikan di SMAIT Al-Qudwah Kota Depok. Sebagai pengontrol, komite sekolah diinformasikan oleh pihak sekolah mengenai bantuan-bantuan dari luar yang akan dan sudah diterima oleh sekolah. Selain itu jika komite sekolah belum memahami tentang penyelenggaraan program sekolah, maka komite sekolah segera respon menanyakan hal tersebut kepada pihak sekolah dan pihak sekolah pun memberikan waktu dan forum khusus untuk menjelaskan program tersebut hingga komite sekolah memahaminya. Evaluasi terhadap programprogram sekolah dilaksanakan secara formal maupun informal setiap tiga bulanan sehingga keterbukaan terhadap penyelengaraan pendidikan pun terlaksana di SMAIT AlQudwah Kota Depok.

4. Mediator antara pemerintah (eksekutif) dengan masyarakat di SMAIT Al-Qudwah Kota Depok.

Dalam menjalankan perannya sebagai mediator antara pihak sekolah dengan warga di lingkungan sekolah komite sekolah di SMAIT Al-Qudwah Kota Depok cukup respon menyelesaikan permasalahan yang ada. Hal ini terbukti dengan senantiasa memberikan masukan terbuka kepada pihak sekolah dan pihak masyarakat di lingkungan sekolah. Komite sekolah juga menjalin kerjasama dengan masyarakat dengan melaksanakan kegiatan yang melibatkan masyarakat di dalamnya. Karena keterlibatan masyarakat merupakan dukungan terbesar untuk 
sekolah. Cara lain dalam meningkatkan kerjasama dengan perorangan dan organisasi belum terperinci dengan jelas.

Tuntutan, keluhan, ide, aspirasi atau masukan dari masyarakat baik itu peserta didik, orang tua peserta didik dan masyarakat umum ditampung oleh komite sekolah untuk disampaikan kepada pihak sekolah. Bahan masukan komite sekolah kepada pihak sekolah adalah dengan meningkatkan jalinan kerjasama yang lebih baik lagi melalui intensitas komunikasi yang terprogram, dan menindaklanjuti pembentukan komite sekolah dengan cepat melalui rapat lanjutan dalam waktu dekat yang membahas dan membentuk struktur kepengurusan komite sekolah. Sehingga komite sekolah dapat membuat program kerja yang bersinergi dengan pihak sekolah.

Untuk dapat melaksanakan peran dan fungsi Dewan Pendidikan dan Komite Sekolah secara maksimal dalam rangka peningkatan mutu layanan pendidikan di sekolah dan daerah, Direktorat Jenderal Manajemen Pendidikan Dasar dan Menengah, melalui kegiatan Pembinaan Dewan Pendidikan dan Komite Sekolah, telah meluncurkan beberapa program dan kegiatan dengan tujuan agar Dewan Pendidikan dan Komite Sekolah dapat melaksanakan peran dan fungsinya secara optimal. Komite sekolah dibentuk di setiap sekolah diharapkan dapat bekerjasama dengan kepala sekolah sebagai partner untuk mengembangkan kualitas sekolah dengan menggunakan konsep Manajemen Berbasis Sekolah dan masyarakat yang demokratis, transparan, dan akuntabel. Pada Undang-undang Nomor 20 Tahun 2003 tentang Sistem Pendidikan Nasional Pasal 56, tercantum bahwa komite sekolah dan madrasah diberikan peran untuk meningkatkan kualitas pelayanan pendidikan melalui: (1) nasihat; (2) pengarahan; bantuan personalia, material dan fasilitas; maupun (4) pengawasan pendidikan.

\subsubsection{Kepengurusan Komite Sekolah \\ Kepengurusan komite} sekolah di SMAIT Al-Qudwah Kota Depok dipilih berdasarkan musyarawah untuk mufakat dengan melibatkan kepala sekolah, guru dan para wakil kepala sekolah serta seluruh orang tua siswa. Sistem pemilihan seperti ini selaras dengan demokrasi pendidikan yang memang sudah selaiknya laksanakan di lingkungan komite SMAIT Al-Qudwah Kota Depok.

Kepengurusan komite di SMAIT Al-Qudwah Kota Depok berlangsung minimal satu periode (tahun) atau sebagaimana kesepakatan bersama artinya jika kepengurusan sebelumnya dianggap masih layak untuk melanjutkan kepengurusan 
berdasarkan

musyawarah

mufakat maka kepengurusan tersebut dapat melanjutkan kembali kepengurusannya. Cara seperti ini juga dinilai sudah cukup menggambarkan dinamika sebuah organisasi yang sehat dimana perubahan organisasi dilakukan dalam jangka waktu tertentu kemudian di evaluasi untuk perbaikan organisasi tersebut kedepannya.

Struktur kepengurusan di SMAIT Al-Qudwah Kota Depok terdiri atas ketua komite, sekretaris dan bendahara. Pembagian kerja kepengurusan dilakukan secara musyawarah mufakat mengingat SMAIT AlQudwah Kota Depok masih terbilang baru berdiri. Pengurus senantiasa berkoordinasi antar sesama pengurus dan dengan pihak sekolah untuk melaksanakan tugas pokok dan fungsinya yang di awal pembentukannya masih serba terbatas.

\subsubsection{Upaya Pemberdayaan Komite Sekolah}

Di awal pembentukannya tugas dan fungsi komite di SMAIT Al-Qudwah Kota Depok masih terbilang sangat terbatas, yakni sebatas memberikan masukan terhadap program yang digulirkan oleh pihak sekolah. Hal ini meliputi turut serta dalam mengawasi jalannya kegiatan akademik dan non akdemik sekolah. Guna melaksanakan tugas tersebut Komite SMAIT
Al-Qudwah Kota Depok membuka komunikasi yang intens dengan pihak sekolah, seperti melaksanakan rapat komite sebulan sekali, dan berkoordinasi dengan pihak sekolah baik secara langsung maupun tidak langsung melalui jaringan telepon, SMS, Whats App, dan surat. Komunikasi yang baik ini menjadi penunjang pihak sekolah dalam memerikan informasi dan menerima masukan-masukan dari komite baik dalam masalah keuangan maupun terkait program akademik, dan kegiatan kesiswaan. Beberapa kendala di awal pembentukan komite sekolah dikarenakan sekolah tersebut masih terbilang baru sehingga para pengurus komite pun belum memahami peran dan tugasnya sebagai komite sekolah. Namun program yang sudah berjalan diantaranya monitoring kegiatan pembelajaran, monitoring kegiatan non akademik siswa, pelaksanaan bakti sosial pada perayaan hari raya Idul Adha di mana komite sekolah bersama sama pihak sekolah dan masyarakat mengadakan penyembelihan hewan Qurban dan membagibagikannya kepada masyarakat sekitar.

Komunikasi yang dilakukan oleh komite sekolah di SMAIT AlQudwah Depok saat ini dilakukan dengan membentuk forum dialog/diskusi baik secara langsung tatap muka dalam rapat-rapat maupun secara tidak langsung tatap muka. 
Terbatasnya waktu yang dimiliki komite sekolah SMAIT AlQudwah Kota Depok dalam menghadiri forum rapat akibat beragamnya profesi dan waktu yang berbenturan dengan kegiatan diluar komite sekolah, maka rapat-rapat komite sekolah hanya dilakukan pada saat yang mendesak dan penting. Hal tersebut tentu saja tidak mengurangi esensi dari pemberdayaan komite sekolah itu sendiri karena disamping komunikasi secara langsung melalui rapat yang terbatas, komunikasi juga dilakukan dengan memanfatakan internet and technology (IT) melalui media sosial seperti facebook, grup whatsap, line, short message sent. Dengan demikian, meskipun intensitas pertemuan secara langsung sedikit terbatas, namun komunikasi dan koordinasi sesama pengurus dan dengan pihak sekolah tetap terjaga dan terpantau.

Forum dialog/diskusi baik secara langsung maupun melalui media sosial ini dilakukan atas inisiatif bersama antara pihak sekolah dengan pengurus komite sekolah. Terjalinnya kerjasama antara pihak sekolah dengan komite sekolah tersebut tidak lepas dari adanya suasana keterbukaan dalam menjalankan peran masing-masing sebagai anggota komite sekolah. Hal tersebut tampak dengan terjalinnya koordinasi dengan komite sekolah untuk membahas program sekolah dan antusiasme pengurus komite sekolah dalam memberikan masukan terhadap program-program yang sedang digulirkan oleh pihak sekolah.

Pemberdayaan komite sekolah di SMAIT Al-Qudwah Kota Depok dalam hal perencaanaan penyelenggaraan program sekolah belum sepenuhnya terlibat. Hal ini ditandai dengan tidak fahamnya pengurus komite sekolah dalam hal penyusunan RAPBS, kalender pendidikan, dan program tahunan sekolah.

Terkait dengan pemberdayaan komite sekolah dalam mengikuti pelatihan/penataran/workshop, saat ini komite sekolah di SMAIT Al-Qudwah Kota Depok belum pernah diikutsertakan. Hal ini dikarenakan pihak komite sekolah sendiri belum memahami sepenuhnya tugas dan fungsinya. Di samping itu pula pihak sekolah sendiri belum memberikan sosialisasi yang jelas dan detail terkait peran dan fungsi komite sekolah kepada para pengurus.

\subsubsection{Pemberdayaan Komite Sekolah Meningkatkan Efisiensi pengelolaan sekolah di SMAIT Al-Qudwah Kota Depok}

Pemberdayaan komite sekolah di SMAIT Al-Qudwah Kota Depok yang masih terbilang baru memberikan dampak yang positif terhadap meningkatnya efisiensi pengelolaan sekolah di sekolah tersebut. Hal ini dikarenakan komite sekolah

Available at:

http://journal.unj.ac.id/unj/index.php/econosains/article/view/696 
intens memberikan sumbangan pemikiran, dana, maupun legitimasi terhadap pengambilan keputusan, pembuatan kebijakan strategis sekolah, dan pengelolaan program kerja sekolah yang berujung pada peningkatan mutu sekolah secara berkesinambungan. Hal ini ditandai dengan terjalinnya komunikasi yang baik antara pihak sekolah dengan komite sekolah dalam hal penerimaan bantuan-bantuan dari luar dan pelaksanaan kegiatan sekolah.

Dampak lainnya dari pemberdayaan komite sekolah di SMAIT Al-Qudwah adalah dukungan pemikiran dan masukan dalam pengelolaan (perencanaan, monitoring, dan evaluasi) program kerja sekolah. Sebagai salah satu sekolah Islam Terpadu, komite sekolah pada SMAIT Al-Qudwah berperan penting bagi keberhasilan penyelengggaraan program sekolah.

Peran yang dominan sering dianggap sebagai kriteria keefektifan dan efisiensi komite sekolah yang berkembang di masyarakat pada umumnya adalah peran dalam hal penyedia keuangan. Sementara kegiatan yang memerlukan pemikiran dan tenaga dari komite, tidak dianggap sebagai tanda keefektifan dan efisiensi pengelolaan sekolah oleh komite sekolah. Kebijakan optimalisasi peran dan fungsi Komite Sekolah merupakan langkah kebijakan yang memiliki peranan dan implikasi penting dalam memenuhi kebutuhan terwujudnya program pendidikan di sekolah yang sesuai dengan konsep Manajemen Berbasis Sekolah. Peran dan tugas komite sekolah tersebut perlu dimaksimakan dalam hal:

1. Penyusunan regulasi tentang Komite Sekolah yang mengakomodir

a. Kebutuhan akan adanya jaminan dan perlindungan hak dan kewajiban Komite sekolah;

b. Sekolah dalam melaksanakan TUPOKSI-nya sesuai dengan $A D / A R T$ yang ditetapkan;

c. Kewenangan dan urusan dalam penanganan dan pengelolaan keuangan;

d. Kewenangan dalam peningkatan dan pengembangan mutu pendidikan di Sekolah;

e. Formulasi standar AD/ART Komite sekolah.

2. Redefinisi Kemitraan antara Komite Sekolah dan Sekolah Perumusan bentuk kemitraan Komite Sekolah dengan Sekolah yang diusulkan adalah berbentuk kerjasama Komite Sekolah dan Sekolah dengan kesetaraan hanya pada sisi tugas dan fungsinya sesuai yang disepakati dalam regulasi/peraturan yang mengikat, sedangkan dari sisi kedudukan kerjasama tetap pihak Sekolah (Kepala Sekolah) berada pada posisi pemimpin. 


\section{KESIMPULAN DAN SARAN}

\subsection{Kesimpulan}

Berdasarkan hasil penelitian dan pembahasan di atsa diperoleh kesimpulan:

1. Pengurus komite sekolah di SMAIT Al-Qudwah Kota Depok terdiri atas beragam profesi dan memiliki jenjang pendidikan minimal Sarjana (S1).

2. Pelaksanaan program kerja komite sekolah di SMAIT AlQudwah Kota Depok belum sepenuhnya berjalan secara efektif. Hal ini ditandai dengan belum fahamnya pengurus komite sekolah terhadap peran dan fungsi komite sekolah dalam meningkatkan efisiensi pengelolaan sekolah di sekolah.

3. Pemberdayaan komite sekolah di SMAIT Al-Qudwah Kota Depok belum sepenuhnya maksimal. Hal ini ditandai dengan masih terbatasnya ruang pemberdayaan bagi pengurus komite sekolah sebagai mitra sekolah. Di samping itu sekolah juga belum sepenuhnya memfasilitasi komite sekolah untuk menggali potensi kepengurusannya sehingga keberadaaannya dapat diberdayakan.

\subsection{Saran}

1. Pihak sekolah hendaknya lebih proaktif melibatkan komite sekolah dalam berbagai pengambilan kebijakan sebagai penunjang kegiatan sekolah, baik dalam bentuk keuangan maupun dalam bidang dukungan non keuangan.

2. Pihak sekolah juga hendaknya memberikan pemahaman yang jelas terkait peran dan fungsi komite sekolah sebagai partner dan bagian penting dari sekolah sehingga peningkatanefiseinsi

pengelolaan sekolah dapat tercapai.

3. Pengurus komite sekolah hendaknya dituntut lebih proaktif dan menggali lebih maksimal potensi yang ada sehingga keberadannya memberikan manfaat yang lebih efisien bagi pengelolaan sekolah.

\section{DAFTAR PUSTAKA}

Arikunto, Suharsimi. (2006). Manajemen Penelitian. Jakarta: Rineka Cipta.

David Silverman. (1994). Interpreting Qualitative Data; Methods for Analysing Talk, Text and Interaction, London: Sage Publication, Ltd.

Depdiknas. (2002). Keputusan Menteri Pendidikan Nasional Republik Indonesia Nomor 044/U/2002 Tentang Dewan Pendidikan dan Komite 
Sekolah. Jakarta:

Depdiknas.

Hadiyanto. (2004). Mencari Sosok Desentralisasi Manajemen Pendidikan di Indonesia. Jakarta: Rineka Cipta.

Hasballah. (2010). Otonomi Pendidikan: Kebijakan Otonomi Daerah dan Implikasinya Terhadap Penyelenggaraan Pendidikan. Jakarta: RajaGrafindo Persada

Hamid Patilima. (2005). Metode Penelitian Kualitatif

Bandung: Alfabeta.

Miles, M.B. \& Huberman, A.M. (1984). Qualitative Data Analysis. Boston: Sage Publications.

Mulyasa. (2006). Manajemen Berbasis Sekolah Konsep Strategi dan Implementasi. Bandung: PT Remaja Rosdakarya

Punaji Setyosari. (2012). Metode Penelitian Pendidikan. (Cetakan ke-2). Jakarta: Predana Media Group.

Robert K.Yin. (2004). Studi Kasus; Desain dan Metode, terjemahan M.Dzauki Mudzakir (Jakarta: PT Raja Grafindo Persada.

Sagala, Syaiful. (2007). Desain Organisasi Pendidikan dalam Implementasi Kebijakan
Otonomi Daerah. Jakarta: Uhamka Press.

Sagala, Syaiful. (2008). Budaya dan Reinventing Organisasi Pendidikan. Pemberdayaan Organisasi Pendidikan ke Arah yang Lebih Profesional dan Dinamis di Provinsi/Kota dan Satuan Pendidikan. Bandung: Penerbit Alfabeta.

Tim Pengembangan Dewan Pendidikan dan Komite Sekolah Direktorat Jenderal Departemen Pendidikan Nasional. (2002). Indikator Kinerja Dewan Pendidikan dan Komite Sekolah. Jakarta; Depdiknas.

http://hdrstats.undp.org/en/count ries/profiles/IDN.html.

http://www.republika.co.id/berita kkoran/newsupdate/13/07/26/mqi6fmkomite-sekolah zisa-picu pungutan

http://www.republika.co.id/berita /pendidikan/beritapendidikan/11/12/16/lwao1 p-icw kewenangan-komitesekolah-kurang-kuat-soaldana-bos

http://www.republika.co.id/berita /pendidikan/beritapendidikan/11/06/07/Imer62 -soal-kisruh komite sekolahsman-70-disdik-dki-angkattangan 
http://www.republika.co.id/berita

/pendidikan/berita-

pendidikan/11/04/07/ja93|-

komite-sekolah di-jambi-

diminta-dievaluasi 